\title{
31. PRELIMINARY REPORT ON URANIUM, THORIUM, AND LEAD CONTENTS AND LEAD ISOTOPIC COMPOSITION IN SEDIMENT SAMPLES FROM THE RED SEA ${ }^{1}$
}

\author{
Maayse H. Delevaux and Bruce R. Doe, U. S. Geological Survey, Denver, Colorado
}

\section{INTRODUCTION}

Table 1 presents data on the uranium, thorium, and lead contents and lead isotopic composition of three sediment samples: one from the metalliferous mud at Site 226 (southwestern Atlantis II Deep) 4.5 meters depth, one from the post-evaporite deposits at Site 227 (eastern flank of Atlantic II Deep) 153.5 meters depth, and one from the dark siltstone within the evaporites at Site 228 (southern Red Sea on the Sudanese or western side) 322 meters depth. Also included are U-Th- $\mathrm{Pb}$ data on pore water and basalt from Site 226 .

The concentration data on the sediments were obtained by isotope dilution on whole-rock samples decomposed with an $\mathrm{HF}-\mathrm{HClO}_{4}$ mixture and dissolved in 1:1 $\mathrm{HNO}_{3}$. A small amount of residue, apparently hematite, remained. If the residue was rich in uranium, thorium, and/or lead, our concentrations of these elements might be low. The isotopic compositions on the sediments were determined on $\mathrm{HNO}_{3}$-soluble lead (1:1) for all three samples, checked by an $\mathrm{HF}-\mathrm{HClO}_{4}$ decomposition on the lead-rich sample from Site 226. No difference was found between the two kinds of analyses of the sample from Site 226.

\section{DISCUSSION}

The isotopic data are plotted on the diagram (Figure 1) along with data on manganese nodules from the ocean basins (Reynolds and Dasch, 1971), metalliferous sediment from the Pacific (Dasch et al., 1971), selected previous lead isotope data from the Red Sea and vicinity (sediments: Cooper and Richards, 1969; brine and galena: Delevaux et al., 1967), and an oceanic basalt isotopic trend line. Data were converted to absolute ratios where necessary. Several features are apparent on the illustration. Most data on Red Sea sediments (mineralized or nonmineralized) plot in the oceanic manganese nodule field. Several samples, including a galena from Rabigh, Saudi Arabia, plot on or near the oceanic volcanic trend line that includes the new analysis on basalt from the Red Sea (Table 1). These isotopic relations were previously observed by Cooper and Richards (1969) and are confirmed by the present study.

\section{Atlantis II Deep}

\section{Lead Isotopes}

The lead in the basalt from Site 226 will be discussed more completely elsewhere in context with studies under progress on volcanic rocks of Saudi Arabia. The important aspect for the purposes of this paper is that the lead isotope

\footnotetext{
${ }^{1}$ Publication authorized by the Director, U.S. Geological Survey.
}

analysis has a normal oceanic volcanic lead isotopic composition which strengthens our assumption that the Red Sea is underlain by normal oceanic mantle.

Most of the lead in the metalliferous Atlantis II Deep sediments has been derived from pelagic sediments. The metalliferous sample from Site 226 in the present study, however, helps confirm Cooper and Richards' (1969) contention, based on brine and near-surface samples, that fairly recently there was an influx of lead ultimately derived from the mantle underlying the Red Sea. This lead could either be derived directly from the mantle or be leached from young volcanics in the Red Sea region.

Although the lead isotopic composition of lead from pore water at Site 226 is similar to that of metalliferous sediment samples in the Atlantis II Deep, surprisingly it is not within the isotope measurement uncertainties of the metalliferous sediment at Site 226, the host of the pore water. In view of the low lead content of the pore water, contamination of the pore water by shipboard sources such as paint and lubricants must be considered. This contamination, if present, is not severe because the pore water lead has a $\mathrm{Pb}^{207} / \mathrm{Pb}^{2} 04$ ratio characteristic of the oceanic mantle, whereas ore lead would be expected to preturb the $\mathrm{Pb}^{207} / \mathrm{Pb}^{204}$ ratio of the pore water lead as well as the $\mathrm{Pb}^{206} / \mathrm{Pb}^{204}$ and $\mathrm{Pb}^{208} / \mathrm{Pb}^{204}$ ratios.

The sediment from Site 227 appears to contain uranogenic pelagic sediment lead but contains the greatest value of $\mathrm{Pb}^{206} / \mathrm{Pb}^{204}$ known for the Red Sea. The value of $\mathrm{Pb}^{208} / \mathrm{Pb}^{204}$, thorogenic lead, in this sample is anomalously low for a pelagic sediment that has such a great value of $\mathrm{Pb}^{206} / \mathrm{Pb}^{204}$. The entire range of lead isotopic compositions for the Red Sea appears to be contained in the Atlantis II Deep.

\section{Uranium-Thorium-Lead Concentrations}

The metalliferous sediment from Site 226, which is iron rich, has an approximately normal thorium content for iron-rich samples but a low uranium content by about a factor of 10 relative to the data on other samples by $\mathrm{Ku}$ (1969). Because we had a few percent residue left in our dissolution, we cannot exclude the possibility that this residue, presumably hematite, had a high uranium content. If so, material balance considerations demand that the uranium content in the residue would have to be about $1000 \mathrm{ppm}$. This high uranium content is unlikely, especially in view of the data on the sample from Site 228 .

The uranium and thorium contents of the pore water are below our limits of sensitivity. The lead content, $0.14 \mathrm{ppm}$, is considerably less than our previous determination of Atlantis II brine at $0.5 \mathrm{ppm}$ (Delevaux et al., 1967). We feel that the lead content of the pore water is close to the real value in view of its low $\mathrm{Pb}^{207} / \mathrm{Pb}^{204}$ ratio which is more 


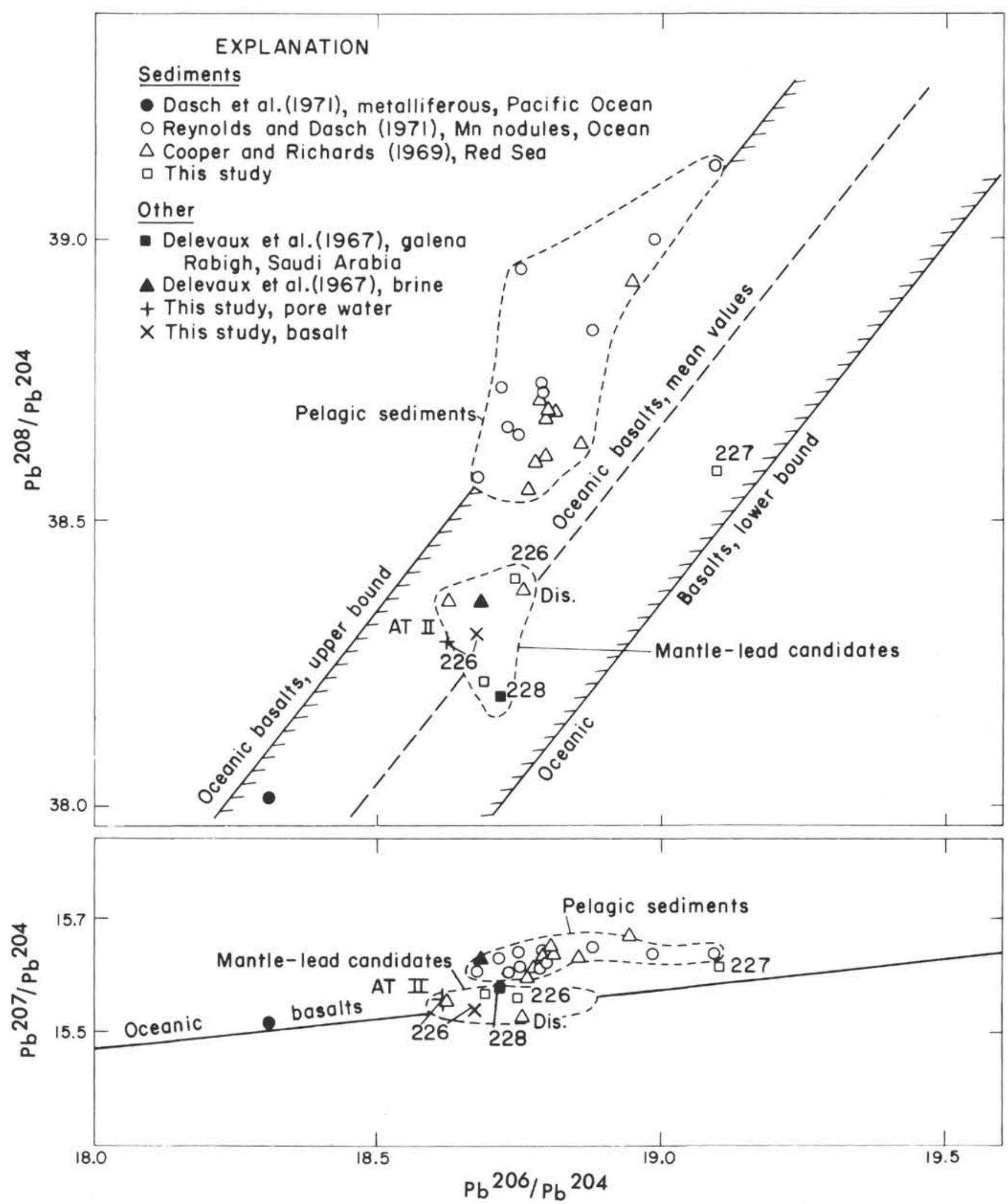

Figure 1. $\mathrm{Pb}^{207} / \mathrm{Pb}^{204}$ and $\mathrm{Pb}^{208} / \mathrm{Pb}^{204}$ versus $\mathrm{Pb}^{206} / \mathrm{Pb}^{204}$ for pelagic sediments, candidates for mantle-derived leads in the Red Sea region, and field for oceanic basalts (which is a close approach to a linear trend on $\mathrm{Pb}^{207} / \mathrm{Pb}^{204}$ versus $\left.\mathrm{Pb}^{206} / \mathrm{Pb}^{204}\right)$. At II, Atlantis II Deep; Dis., Discovery Deep. 
TABLE 1

Preliminary Data on Uranium, Thorium, and Lead Contents and Lead Isotopic Composition in Sediments of the Red Sea, Leg 23

\begin{tabular}{ccccccc}
\hline & \multicolumn{3}{c}{ Concentrations (ppm) } & \multicolumn{3}{c}{ Isotopic Ratios (atomic, absolute) } \\
\cline { 2 - 7 } Sample & $\mathrm{U}$ & $\mathrm{Th}$ & $\mathrm{Pb}$ & $\mathrm{Pb}^{206} / \mathrm{Pb}^{204}$ & $\mathrm{~Pb}^{207} / \mathrm{Pb}^{204}$ & $\mathrm{~Pb}^{208} / \mathrm{Pb}^{204}$ \\
\hline $226-1-4^{\mathrm{a}}$ & 1.17 & 0.12 & 150 & 18.742 & 15.562 & 38.400 \\
$226-1-4-1 \mathrm{~W}$ & $\leqslant 0.002$ & $\leqslant 0.0006$ & 0.14 & 18.617 & 15.561 & 38.291 \\
$226-2-1^{\mathrm{b}}$ & - & - & - & 18.672 & 15.543 & 38.307 \\
$227-20-4^{\mathrm{c}}$ & 11.1 & 2.29 & 14.7 & 19.095 & 15.615 & 38.583 \\
$228-39-1^{\mathrm{c}}$ & 1.56 & 1.04 & 63.9 & 18.690 & 15.568 & 38.212 \\
\hline
\end{tabular}

a Average of $50 \% \mathrm{HNO}_{3}$ leach and $\mathrm{HF}-\mathrm{HClO}_{4}$ dissolution analyses for lead isotopic composition. No analytically significant difference was observed. Concentrations are by isotope dilution on an $\mathrm{HF}-\mathrm{HClO}_{4}$ dissolution. A few percent residue remained, presumably hematite.

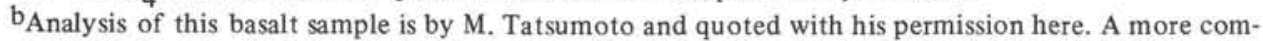
plete discussion of this sample in context with data from other volcanic rocks of the Red Sea region now under study will appear elsewhere.

${ }^{c}$ Lead isotopic composition is on $50 \% \mathrm{HNO}_{3}$ leaches. Concentration data are by isotope dilution on $\mathrm{HF}-\mathrm{HClO}_{4}$ dissolutions. Residue, presumably hematite, is minor.

characteristic of the mantle than crustal sources such as most ore leads.

The sample from Site 227 appears to be a calcareous sample of fairly normal lead content. For it, too, the thorium content (2.29 ppm) seems to be "normal" for calcareous samples, but the uranium content is high by a factor of 10 relative to other such samples reported by $\mathrm{Ku}$ (1969). Our uranium concentration on this sample does seem to be more like that expected in a shale rather than in a calcareous rock. The residue in the $1: 1 \mathrm{HNO}_{3}$ leach was, however, 31 percent of the sample treated, whereas residues in the other two samples were 41 and 49 percent. We have no explanation for the anomalously great uranium content, but it does not appear to be an analytical artifact.

Both samples of the Atlantis II Deep show an inverse relationship between the lead content and the uranium and thorium contents.

\section{Discovery Deep}

\section{Lead Isotopes}

The near-surface sediments in the Discovery Deep also appear to contain lead with mantle isotopic characteristics (Cooper and Richards, 1969). Deeper sediments contain pelagic sediment lead similar to the relations found for the Atlantis II Deep.

\section{Southern Red Sea}

\section{Lead Isotopes}

A sample from near the bottom of the core from the southern Red Sea, Site 228, appears to contain lead with mantle isotopic characteristics. This sample is a shaly fraction from the evaporite sequence in which sphalerite lenses have been identified by R. G. Coleman (oral communication, 1973) who suggests that such evaporites are an ideal source for much of the elemental enrichments found in the metalliferous sediments of the deeps. This hypothesis would in turn indicate that the mantle-derived lead in the sample from a shaly fraction in the evaporite sequence of Site 228 and some of the metalliferous samples of the deeps was more likely derived through weathering of volcanic sequences rather than as a direct introduction from the mantle.

\section{Uranium-Thorium-Lead Concentrations}

The concentrations of uranium, thorium and lead in the sample from Site 228 in the southern Red Sea are roughly compatible with those in the other two samples. The lead content on this low-residue sample is intermediate between that in the other two samples and so are the uranium and thorium concentrations. Accordingly, we believe that the apparently low uranium content in the sample from Site 226 , which had significant residue, is not an analytical artifact, but that the uranium and thorium are in an inverse relation to the lead content.

\section{Conclusions}

1) Leads in the near-surface sediments of the Atlantis II and Discovery deeps and from a deeper shaly fraction of an evaporate sequence in the southern Red Sea contain lead dominantly of mantle derivation. Because the evaporite sequences appear to be an ideal source for derivation of at least some of the metalliferous sediments in the deeps, the mantle-derived lead would appear to be more likely derived through weathering of young mantle-derived volcanics of the Red Sea region rather than through a recent influx of lead from the underlying mantle.

2) Leads from deeper sediments in the Red Sea cores such as the sample from Site 227 appear to be of pelagic sediment derivation as previously determined by Cooper and Richards (1969).

3) There is the suggestion from three samples of an inverse relationship between both uranium and thorium contents with lead content. 


\section{REFERENCES}

Cooper, J. A. and Richards, J. R., 1969. Lead isotope measurements on sediments from Atlantis II and Discovery Deep areas. In Hot brines and recent heavy metal deposits in the Red Sea; Degens, E. T. and Ross, D. A. (Eds.), New York (Springer-Verlag), p. 499-511.

Dasch, E. J., Dymond, J. R., and Heath, G. R., 1971 Isotopic analysis of metalliferous sediment from the East Pacific Rise: Earth Planet. Sci. Lett., v. 13, p. 175-180.

Delevaux, M. H., Doe, B. R., and Brown, G. F., 1967 Preliminary lead isotope investigations of brine from the
Red Sea, galena from the Kingdom of Saudi Arabia, and galena from the United Arab Republic (Egypt): Earth Planet. Sci. Lett., v. 3, p. 139-144.

$\mathrm{Ku}$, Teh-Lung, 1969. Uranium series isotopes in sediments from the Red Sea Hot-Brine area. In Hot brines and recent heavy metal deposits in the Red Sea: Degens, E. T. and Ross, D. A. (Eds.), New York (Springer-Verlag), p. $512-524$.

Reynolds, P. H. and Dasch, E., 1971. Lead isotopes in marine manganese nodules and the ore-lead growth curve: J. Geophys. Res., v. 76, p. 5124-5129. 